\title{
Human Monoclonal Antibody B11-hCG Beta Fusion Protein CDX-1307
}

\author{
National Cancer Institute
}

\section{Source}

National Cancer Institute. Human Monoclonal Antibody B11-hCG Beta Fusion Protein

CDX-1307. NCl Thesaurus. Code C77858.

\begin{abstract}
A human monoclonal antibody (B11) directed ag ainst the mannose receptor and linked to the beta-subunit of human chorionic gonadotropin (hCG beta) with potential immunostimulating and antineoplastic activities. The monoclonal antibody moiety of human monoclonal antibody B11-hCG beta fusion protein CDX-1307 binds to mannose receptors on antigen presenting cells (APCS), including human dendritic cells (DCS) and macrophages. Upon internalization and processing, APCs present the processed hCG beta antigen on their cell surfaces, which may initiate an antibody-dependent cellmediated cytotoxicity (ADCC) response against hCG beta-expressing tumor cells. The tumor-associated antigen (TAA) hCG beta is selectively overexpressed by a number of tumors including breast, colorectal, pancreatic, bladder and ovarian tumors; its expression may correlate with the stage of disease.
\end{abstract}

